\title{
Research on Three - Dimensional Education Mode of College Counselors in New Area
}

\section{Fengchen Guo}

Jilin Engineering Normal University, Changchun, Jilin, 130052

Keywords: College counselors; three-dimensional; education model; innovative practice

\begin{abstract}
With the continuous development of modern education, three-dimensional education has gradually become an important way to train qualified personnel in colleges and universities. In practice, not only should students be admitted with professional degrees, but also should be based on professional ability, moral quality and psychological quality All-round training to ensure that students can successfully transition from school to society. Counselors are an important factor in the management of college education and teaching, and their natural relationship with students determines their importance in implementing the three-dimensional teaching model. Based on this, starting from the basic content of the three-dimensional teaching model, this paper studies the development ideas and innovation paths of the tutor's three-dimensional education model in the new era.
\end{abstract}

\section{Introduction}

Three-dimensional education is a set of academic education, ability training, quality shaping, career orientation as one of the all-round, diversified education model. In college personnel training, academic education is the most basic content of education and training, but also the talent into the job market, "professional certification"; ability training refers to the students formed during the professional life skills, interpersonal skills, communication and exchange Ability to self-education, practical ability, some of these abilities can be used to reflect the professional certificate, while others internalize into the personal qualities of students and career planning to be reflected in the quality of shaping, which includes not only the students' basic professional ethics , But also include personal ethics, political literacy, psychological qualities, such as teamwork, crisis awareness, innovative spirit, sense of responsibility, etc .; career orientation refers to the professional evaluation of students in the professional learning process, which not only defines the professional learning The content, but also planning the future direction of employment. In college education system, counselors, as a bridge between schools and students, not only need to implement the norms of teaching management in schools, but also should design a more acceptable mode of education and training for students according to the actual situation of class management, in order to achieve the three-dimensional cultivation of students.

\section{The new era of college counselors three-dimensional education mode of expression}

In the new era of personnel training in colleges and universities, the three-dimensional education model for education and teaching innovation provides an important idea, especially in the context of the continuous development of information, the university's education structure, knowledge content, education methods are profound Change, and counselors as a bridge between schools and students, their work should be conducted on the three-dimensional teaching performance analysis in-depth manner. Specifically, the principle of the three-dimensional education model mainly as follows: First, the three-dimensional education principle. In the traditional university education and training, to follow the law of development of education and improve students' overall accomplishment is the basic principle, but in the three-dimensional education model, this over-generalization of the counselor's work has brought some difficulties, therefore , In order to achieve the three-dimensional cultivation of students, their education principles should be adjusted, that is, a combination of 
diversified personnel training and unification of education, professional knowledge learning and ability to combine the high standards and strict requirements and respect students Combine. Second, three-dimensional education. Different teaching and training objectives of the selected teaching methods are different, therefore, counselors in the work, should be from a diversified perspective, in order to ensure the overall professionalism and professionalism of students to enhance, such as the use of heuristic education, guidance Students 'ability to question, promote their independent thinking, use situational education, inspire college students' multiple emotions, deepen the impression of educational content, use simulated education to play the role of multimedia technology, and demonstrate the effectiveness of modern education. Third, three-dimensional learning. The three-dimensional education mode is not only the basic mentor for counselors to guide students, but also an important way for students to achieve self-learning. Under the continuous development of modern educational technology, counselors should make use of educational network platform to provide more interaction between teachers and students Convenient space, at the same time with the online education resources, to provide more suitable for their college students learning content education content, such as the use of WeChat public push to expand the coverage of ideological and political education, use of social platforms and online communication with students to promote teachers and students The harmonious development of relations. Fourth, the three-dimensional level of education. Three-dimensional education is not only refers to the three-dimensional horizontal development of individual students ability, but also reflected in the collective vertical education of students three-dimensional, for college counselors, their work, should be based on different professional achievements, different regions, different interests , Different career planning and other factors, the level of students, and targeted selection of different teaching methods, so as to fully reflect the development of three-dimensional education needs and truly achieve the development of three-dimensional education requirements.

\section{The new era of college counselors three-dimensional education development ideas}

Into the new period of education development, college counselors three-dimensional education not only catered to the development of counselors personal career development plan, but also in line with the development of the times for the contemporary college students put forward new requirements. Based on this, counselors in education and teaching management should be based on the objective reality of college students, as well as the needs of the development of education in the era, the development of three-dimensional education model for the design ideas: First, the development of professional quality, counselors not only to Itself as a link between students and schools, but also as a professional educator, and from the perspective of education to develop their own professional ability, to provide three-dimensional support for college students; Second, the development of integrated management, at work, counseling For the management of class should be comprehensive, not only from the perspective of career development of students to do a good job in education and practice management, but also from the perspective of individual development of students to achieve ideological and moral, political and psychological qualities of education and guidance; Third, career planning , College counselors should regard three-dimensional education as an innovative model for students and self-development to promote professional and standardized development of counselors' work.

\section{The new era of college counselors three-dimensional education innovation and practice}

Career philosophy is the overall understanding of the profession. Judging from the actual work of counselors in colleges and universities, the old and rigid work philosophy remains a major obstacle that restricts many counselors from achieving professional and specialized development. At present, due to the college counselor team construction has not formed a systematic management system, many counselors just use the profession as the future of career planning "springboard", this short career planning is naturally difficult for it to devote all their energy, Therefore, the development of professional ideas will be more conservative, stick to the rules, do not want or can 
not make changes. Under the new situation of education development, colleges and universities should actively adjust the management system of counselors so as to promote the innovation of their professional ideas. That is, on the one hand, they should establish a people-oriented educational concept, take college students as the core of education management and from the current social development The actual situation, to provide more conducive to college students to develop their professional skills, improve ideological and political education content to build a good teaching management atmosphere; on the other hand to establish the concept of innovation in the work with innovative ways to stimulate college students' sense of innovation, So that it can stimulate innovative thinking in professional learning and cultivate innovative ability, so as to adapt more to the requirements of the development of the times for the quality of qualified personnel.

The development of vocational ability is the key to the college counselors to implement the three-dimensional education mode. The so-called "blacksmith needs its own hard," counselors as the implementation of teaching and administrative management of higher education carrier, the level of their professional ability directly determines the effect of three-dimensional teaching practice is good or bad. Under the new educational environment, colleges and universities also put forward new requirements for the professional ability of counselors: First, to clarify their own responsibilities and improve their professional theoretical accomplishments. In the teaching management of colleges and universities, counselors are both teachers and not only Teachers, he and other professional teachers together to carry out the basic teaching tasks of educating people, but also need to assume the primary responsibility for moral education, and cooperate with the school to do a good job of student work, and based on multiple demands, and only in professional theoretical literacy Excellent premise, in order to balance various roles, travel professional responsibility. Second, careful and patient should be the basic attitude of their work, counselors and students daily life, learn to contact, and in the trivial, complex work content, only to ensure careful, patient, can take responsibility for the work and timely detection Students in professional learning, psychological development, ideological problems in the construction, combined with the requirements of three-dimensional education work guidance program. Third, to expand the field of knowledge, self-education planning with the requirements of compound talents, with the continuous development of information technology, knowledge updating faster and faster, and college counselors for the implementation of three-dimensional education requires management science, Psychology, sociology and other aspects of knowledge, therefore, in the career planning should continue to broaden the knowledge, improve the ability to deal with student education and teaching management.

In the new era background, the contents of college counselors should ensure that advance with the times, provide three-dimensional education for students the necessary support. In terms of innovating the content of work, college counselors should first pay attention to the innovation of ideological and political education contents. The ideological and political education work is the basic content of college counselors' work and also a common issue among college students. Under the background of information age, the traditional Therefore, counselors should make new explanations on ideological and political education based on the hot issues of politics at home and abroad so as to ensure the novelty of educational content and inspire college students to care for the society and care for the development of the times Enthusiasm; Second, do a good job of psychological education guidance, in recent years, the media exposed the hot spots in the community, the presence of college students is always a sign of sorrow, which to some extent that the psychological health of contemporary college students has reached a However, counselors, as the leader of student service, should take the initiative to infiltrate the psychological health education in their management. They should not only help college students to break through the psychological misunderstanding from the perspective of study and employment, but also should take the development of individual ideological and moral qualities, Strengthen the heart Education, so that students realize the physical and mental development.

Work style is the way of presenting work content. As the main body of education, college counselors are closely related to the students. In the teaching management practice, they should 
combine the requirements of the three-dimensional education model to innovate their working methods and make the students easier to accept to achieve education guide, and then to build a comprehensive three-dimensional development of college students a good learning environment. In the process of innovative work methods, counselors can use the way of life, to put down the identity gap between students, from the daily life of students, learning to start by investigating college students' attitude to future employment, evaluation of self-development Content, with a approachable attitude as a student life mentor, abandon the traditional preaching caused by communication barriers, so that teachers and students in equal communication, establish mutual trust, and thus form a harmonious relationship between teachers and students. In addition, counselors should also pay attention to the value of practice. Practice is the main way to improve students' ideological understanding. Counselors should not only introduce their students into practice but also conduct long-term instillation with their target students. For example, social investigation, volunteer service, Cultural activities, etc., so that students form a new understanding of themselves, others, and society in various forms of practice, so as to realize the common development of ideological education and vocational education.

\section{Conclusion}

In short, under the new education situation, the status of college counselors' teaching management has also undergone some changes. As an important factor in personnel training, on the one hand, schools should attach importance to the construction of professional counselors, from the perspective of professionalization and standardization On the other hand, counselors should also carry out innovative practices in accordance with the new requirements and new ideas of personnel training from the perspective of three-dimensional education so as to ensure the education of academic qualifications, ability cultivation and quality of undergraduates Shape, career orientation and common development, provide more high-quality talents for social development.

\section{Acknowledgements}

Project Title: Jilin Province 13th Five-year Planning for Strategic Thinking of the special issue of ideological and political research GS17128, counselors in the new media era of political and ideological education "three-dimensional model of educating people"

\section{References}

[1] Sun Tingting. Study on Political and Ideological Working Methods of College Counselors under the Background of Internet [J]. News Economy Information, 2017, (14): $449+463$.

[2] Wang Lin. A summary of the latest research on the effective incentive of college counselors [J]. Modern Commerce and Industry, 2016,37 (10): 88-89.

[3] Wang Yichao. A Brief Talk on the Deficiency and Innovation of College Counselors' Ideological and Political Education in the New Era [J]. Tzu Zi (Upper Intermediate), 2015, (12): 62.

[4] Li Yun. Analysis of adaptability of college freshmen from the perspective of counselors [J]. Res. Intelligence, 2014, (01): 148. 